\title{
IMPLEMENTASI MOTIVASI, PENGEMBANGAN SUMBER DAYA MANUSIA, KOMITMEN, KEPUASAN DAN KINERJA
}

\author{
Aris Tri Haryanto ${ }^{1}$, Jarot Santosa ${ }^{2}$, BRM. Suryo Triono ${ }^{3}$ \\ Sekolah Tinggi Ilmu Ekonomi Adi Unggul Bhirawa Surakarta, Sekolah Tinggi Ilmu \\ Ekonomi Adi Unggul Bhirawa Surakarta, Sekolah Tinggi Ilmu Ekonomi Adi Unggul \\ Bhirawa Surakarta \\ Email : Arisharyanto26@yahoo.co.id
}

\begin{abstract}
Abstrak
Penelitian ini bertujuan untuk membuktikan secara empiris pengaruh motivasi dan pengembangan sumber daya manusia terhadap komitmen dalam meningkatkan kepuasan dan kinerja pegawai Dinas Sosial Kabupaten Magetan. Populasi dalam penelitian ini adalah pegawai Dinas Sosial Kabupaten Magetan yang berjumlah 188 orang. Teknik pengambilan sampel menggunakan teknik random sampling. Peneliti mengambil sampel $40 \%$ dari jumlah populasi, sebanyak 25\% X 188 pegawai $=47$, dibulatkan menjadi 50 responden. Hasil penelitian menunjukkan motivasi dan pengembangan SDM berpengaruh signifikan terhadap komitmen organisasi. Motivasi dan komitmen organisasi berpengaruh tidak signifikan terhadap kepuasan. Pengembangan SDM berpengaruh signifikan terhadap kepuasan. Motivasi, pengembangan SDM, komitmen organisasi dan kepuasan berpengaruh signifikan terhadap kinerja pegawai. Hasil uji $F$ dapat disimpulkan secara bersama-sama variabel motivasi, pengembangan SDM, komitmen organisasi dan kepuasan mempengaruhi Kinerja pegawai di Dinas Sosial Kabupaten Magetan. Nilai $R^{2}$ total sebesar 0,564 dapat diartikan variasi Kinerja Pegawai di Dinas Sosial Kabupaten Magetan dijelaskan oleh variabel Motivasi, Pengembangan SDM, Komitmen organisasi dan kepuasan sebesar 56,4\% dan sisanya 43,6\% dijelaskan variabel lain diluar model penelitian sebagai contoh kompetensi, pelatihan dan lain sebagainya.
\end{abstract}

Kata Kunci : Motivasi, Pengembangan Sumber Daya Manusia, Komitmen, Kepuasan, Kinerja Pegawai

\section{LATAR BELAKANG MASALAH}

Peningkatan kinerja dapat dilakukan dengan terciptanya komitmen organisasi sebagai fundamen terciptanya keselarasan aktivitas sumber daya manusia (SDM) merupakan salah satu aset yang tidak ternilai harganya karena dapat memberikan kontribusi yang berarti kepada satuan kerja secara efektif dan efisien, produktif dan kompetitif. Sumber daya manusia merupakan salah satu unsur yang sangat penting bagi organisasi terutama dalam peningkatan pelayanan kepada masyarakat. Agar tujuan organisasi dapat terwujud dan mendorong penyempurnaan berbagai sistem dalam pengelolaan sumber daya manusia yang mengarah pada bagaimana memberdayakan sumber daya manusianya. Perlu upaya pelaksanakan pengembangan SDM oleh setiap organisasi dalam rangka mewujudkan pembangunan sumber daya manusia dalam setiap aspek kehidupan berorganisasi khususnya dalam pengelolaan pegawai.

Masalah peningkatan sumber daya manusia merupakan salah satu unsur yang sangat penting bagi organisasi terutama dalam peningkatan pelayanan kepada masyarakat termasuk didalamnya adalah pegawai Dinas Sosial Kabupaten Magetan. Oleh karena itu upaya perbaikan apapun yang dilakukan untuk meningkatkan kualitas 
kerja tidak akan memberikan sumbangan yang signifikan tanpa di dukung oleh pegawai yang profesional dan berkualitas. Sebagai pegawai merupakan salah satu faktor penentu keberhasilan setiap upaya pegawai. Kinerja pegawai dalam merencanakan dan melaksanakan pembelajaran, merupakan faktor utama dalam pencapaian tujuan erat kaitannya dengan tugas dan tanggung jawab pegawai sebagai komponen instansi.

Kinerja pegawai menjadi masalah yang cukup penting, karena terbukti besar manfaatnya bagi kepentingan individu terutama pegawai dan organisasi pada umumnya. Pengertian kinerja pada dasarnya adalah kegiatan dan hasil yang dapat dicapai atau dilanjutkan seseorang atau sekelompok orang didalam pelaksanaan tugas, pekerjaan dengan baik, artinya mencapai sasaran atau standar kerja yang telah ditetapkan sebelum dan atau bahkan dapat melebihi standar yang ditentukan oleh perusahaan pada periode tertentu,"(Handoko, 2017). Keberhasilan Dinas Sosial Kabupaten Magetan dalam menarik kepercayaan masyarakat tidak terlepas dari kinerja pegawai yang tinggi. Prestasi tersebut dapat bertahan dan ditingkatkan perlu dilakukan evaluasi dan penelitian terhadap Pengembangan Sumber Daya Manusia agar kebijakan yang diambil pada masa depan mampu meningkatkan kinerja pegawai.

Kinerja adalah gambaran mengenai tingkat pencapaian pelaksanaan suatu kegiatan atau program atau kebijakan dalam mewujudkan sasaran, tujuan, misi dan visi organisasi yang tertuang dalam rencana strategi suatu organisasi. Mengacu pendapat tersebut di atas dapat diambil kesimpulan bahwa kinerja adalah hasil kerja yang dicapai oleh seorang pegawai melalui suatu pelaksanaan pekerjaan atau tugas yang dibebankan kepadanya sesuai dengan waktu yang telah ditentukan, bermutu, tepat mengenai sasaran dengan selalu mengikuti metode yang telah ditetapkan (Mahsun, 2016), sedangkan kinerja dapat didefinisikan sebagai hasil yang dicapai oleh seseorang menurut ukuran yang berlaku bagi pekerjaan yang bersangkutan (Handoko, 2012).

Menurut Handoko (2012) mengatakan bahwa motivasi ialah dorongan kerja yang timbul pada diri seseorang untuk berperilaku dalam mencapai tujuan yang telah ditentukan. Siagian (2012) mengatakan yang dimaksud dengan motivasi adalah daya pendorong yang mengakibatkan seseorang anggota organisasi mau dan rela untuk menggerakkan kemampuan dalam bentuk keahlian atau ketrampilan tenaga dan waktunya untuk menyelenggarakan berbagai kegiatan yang menjadi tanggungjawabnya dan menunaikan kewajibannya, dalam rangka pencapaian tujuan dan berbagai sasaran organisasi yang telah ditentukan sebelumnya. Sasaran motivasi adalah untuk mencapai rasa memiliki tujuan bersama dengan memastikan bahwa sejauh mungkin keinginan dan kebutuhan organisasi serta keinginan dan kebutuhan para pegawai Dinas Sosial Kabupaten Magetan berada dalam keadaan yang harmonis. Pemberian motivasi yang tepat akan mendorong pegawai untuk berbuat sebesar dan sekuat mungkin dalam melaksanakan tugas, dan dia yakin bahwa keberhasilan Dinas Sosial Kabupaten Magetan dalam mencapai tujuan dan sasaran kepentingan pribadi turut terpelihara.

Peningkatan Pengembangan Sumber Daya Manusia berdasarkan pada pengembangan SDM masing - masing pegawai dilakukan agar dapat memberikan hasil sesuai dengan tujuan dan sasaran organisasi dengan standar kinerja yang telah ditetapkan. Pengembangan SDM yang dimiliki seorang karyawan secara individual harus dapat mendukung pelaksanaan visi misi organisasi melalui kinerja strategis tersebut. Oleh karena itu kinerja individu dalam organisasi merupakan jalan dalam meningkatkan produktivitas organisasi itu sendiri. Pengembangan SDM adalah karakteristik mendasar yang dimiliki seseorang yang berpengaruh langsung terhadap, atau dapat memprediksikan kinerja yang sangat baik (Sedarmayanti, 2008). Wibowo 
(2017) menyebutkan bahwa pengembangan SDM adalah suatu kemampuan untuk melaksanakan atau melakukan suatu pekerjaan atau tugas yang dilandasi atas keterampilan dan pengetahuan serta didukung oleh sikap kerja yang dituntut oleh pekerjaan tersebut. Dengan demikian, pengembangan SDM menunjukkan keterampilan atau pengetahuan yang dicirikan oleh profesionalisme dalam suatu bidang tertentu sebagai sesuatu yang terpenting, sebagai unggulan bidang tertentu.. Pengembangan SDM sebagai karakteristik seseorang berhubungan dengan kinerja yang efektif dalam suatu pekerjaan atau situasi. Hal ini sesuai dengan penelitian yang dilakukan oleh Dhermawan dkk (2012), Yunus (2013), bahwa pengembangan SDM berpengaruh terhadap kinerja pegawai.

Komitmen organisasi adalah tingkat kepercayaan dan penerimaan tenaga kerja terhadap tujuan organisasi dan mempunyai keinginan untuk tetap ada di dalam organisasi tersebut yang pada akhirnya terjadi dalam statistik ketidakhadiran dan masuk keluar tenaga kerja (turnover). Seseorang akan memiliki komitmen yang tinggi jika pekerjaan yang menjadi tanggungjawabnya lebih baik, memberikan otonomi yang luas dalam pengambilan keputusan dan memberikan penghargaan yang layak.

Kepuasan kerja berperan penting dalam meningkatkan kinerja pegawai Dinas Sosial Kabupaten Magetan. Kepuasan kerja pegawai selama ini masih ditemukan permasalahan yang disebabkan oleh pekerjaan yang dilaksanakan yaitu ada pegawai yang bekerja dengan hasil pekerjaan yang baik, tetapi ada oknum pegawai yang bekerja dengan hasil pekerjaan tidak baik. Kondisi ini biasanya akan menimbulkan ketidakpuasan kerja bagi pegawai yang telah bekerja dengan baik sehingga dapat menurunkan kinerja pegawai. Menurut Handoko (2012) bahwa pegawai yang tidak memperoleh kepuasan kerja akan cepat bosan, sering absen dan melakukan kesibukan yang tidak ada hubungannya dengan pekerjaan yang harus dilakukan sehingga kondisi ini dapat berdampak pada menurunnya kinerja pegawai. Hasil penelitian yang relevan dilakukan oleh Ferum Mahendra Pranita (2017) menyatakan bahwa kepuasan berpengaruh signifikan terhadap kinerja. Bertitik tolak dari permasalahan maupun fenomena yang ada di Dinas Sosial Kabupaten Magetan yang telah diuraikan diatas, maka penelitian ini mengambil judul "Implementasi Motivasi, Pengembangan Sumber Daya Manusia, Komitmen, Kepuasan, Kinerja".

\section{LANDASAN TEORI Kinerja}

Pabundu (2012) mendefinisikan kinerja merupakan hasil fungsi pekerjaan atau kegiatan seseorang atau kelompok dalam suatu organisasi yang dipengaruhi oleh berbagai faktor untuk mencapai tujuan organisasi dalam periode waktu tertentu. Kinerja dalam penelitian ini adalah tingkat keberhasilan pegawai dalam melaksanakan tugas dan tanggung jawabnya serta kemampuan untuk mencapai tujuan dan standar yang telah ditetapkan organisasi. Kinerja diukur dengan menggunakan indikator menurut Mahsun, (2013) masukan (input), proses (process), keluaran (output), hasil (outcome), manfaat (benefit) dan dampak (impact) terhadap suatu pekerjaan yang dihasilkan.

\section{Kepuasan}

Kepuasan kerja merupakan sikap atau rasa bagi pegawai di lingkungan organisasi terhadap pekerjaan yang ada pada saat ini berdasarkan masing-masing 
jabatan dan bagian yang mereka miliki pada sebuah organisasi tersebut. Kepuasan kerja diukur dengan menggunakan indikator menurut Manullang, (2012) adalah gaji, keamanan kerja, kondisi kerja, kesempatan untuk maju dan jenis pekerjaan yang diberikan kepada setiap pegawai.

\section{Motivasi}

Motivasi merupakan segala sesuatu yang menjadi pendorong tingkah laku yang menuntut atau mendorong orang untuk memenuhi suatu kebutuhan. (Siagian ; 2012). Motivasi kerja adalah kekuatan dan dorongan yang timbul dalam diri pegawai untuk berusaha seoptimal mungkin dalam mencapai tujuan dengan dipengaruhi oleh kemampuan usaha untuk memuaskan kebutuhan. Motivasi diukur dengan memodifikasi indikator yang dikembangkan oleh Ambar (2013) menggunakan indikator: keberhasilan pelaksanaan, pengakuan, pekerjaan itu sendiri, tanggung jawab dan pengembangan.

\section{Pengembangan SDM}

Pengembangan SDM merupakan usaha-usaha yang dilakukan untuk meningkatkan keterampilan dan pengetahuan pegawai pada sebuah organisasi. Menurut Wibowo (2012) indikator yang tepat dalam mengukur pengembangan SDM diantaranya adalah: metode pengembangan yang diberikan kepada pegawai, pelatihan yang diikuti, promosi, ketrampilan dan pengetahuan dan keahlian dan kecakapan.

\section{Komitmen}

Komitmen organisasional dapat didefinisikan sebagai kekuatan yang bersifat relasi dari individu dalam mengidentifikasi keterlibatan dirinya kedalam organisasi. (Porter dalam Keith Davis ; 2011). Komitmen organisasi dapat diukur dengan memodifikasi indikator yang dikembangkan oleh Mayer dan Allen dalam Trisnaningsih (2012) yang menggunakan indikator perasaan ikut memiliki, ikatan emosional, perasaan bangga dengan organisasi, merasa menjadi bagian organisasi dan berjuang memajukan organisasi.

\section{METODE PENELITIAN}

Penelitian ini merupakan penelitian kuantitatif, dengan menggunakan data primer. Populasi dalam penelitian ini adalah pegawai Dinas Sosial Kabupaten Magetan yang berjumlah 188 orang. Teknik pengambilan sampel menggunakan teknik Random Sampling. Peneliti mengambil sampel $40 \%$ dari jumlah populasi, sebanyak $25 \%$ X 188 pegawai $=47$, dibulatkan menjadi 50 responden. Teknik analisis menggunakan path analysis dengan melihat pengaruh langsung dan tidak langsung.

\section{HASIL DAN PEMBAHASAN}

\section{Hasil Uji Instrument}

Hasil uji validitas dengan membandingkan nilai $r_{\text {hitung }}$ lebih besar dari nilai $r_{\text {tabel }}=$ 0,273 dan didapatkan hasil dari seluruh item pertanyaan Motivasi, Pengembangan Sumber Daya Manusia, Komitmen, Kepuasan, Kinerja semua valid. Hasil pengujian reliabilitas menunjukkan bahwa koefisien (r) alpha hitung seluruh variabel lebih besar 
dibandingkan dengan kriteria yang dipersyaratkan atau nilai kritis (rule of thumb) sebesar 0,6 sehingga dapat dikatakan bahwa butir-butir pertanyaan seluruh variabel dalam keadaan reliabel

Tabel 1. Hasil Uji Reliabilitas

\begin{tabular}{cccc}
\hline Variabel & $\begin{array}{c}\text { Alpha } \\
\text { Cronbach }\end{array}$ & Kriteria & Keterangan \\
\hline Motivasi & 0,781 & Alpha & Reliabel \\
Pengembangan SDM & 0,856 & Cronbach $>0,60$ & Reliabel \\
komitmen organisasi & 0,775 & maka reliable & Reliabel \\
Kepuasan & 0,813 & & Reliabel \\
Kinerja & 0,763 & & Reliabel \\
\hline
\end{tabular}

Sumber : Data yang diolah, 2020

\section{Hasil Analisis Jalur (Path Analysis)}

Hasil Analisis Jalur Persamaan 1

Tabel 2. Hasil Analisis Jalur Persamaan 1

Coefficients

\begin{tabular}{|ll|r|r|r|r|r|}
\hline \multirow{2}{*}{ Model } & \multicolumn{2}{|c|}{$\begin{array}{c}\text { Unstandardized } \\
\text { Coefficients }\end{array}$} & \multicolumn{2}{c|}{$\begin{array}{c}\text { Standardized } \\
\text { Coefficients }\end{array}$} & & \\
\cline { 3 - 4 } & & \multicolumn{1}{|c|}{$\mathrm{B}$} & Std. Error & \multicolumn{1}{c|}{ Beta } & \multicolumn{1}{c|}{$\mathrm{t}$} & \multicolumn{1}{c|}{ Sig. } \\
\hline 1 & (Constant) & 10,965 & 1,918 & & 5,716 &, 000 \\
& Motivasi &, 266 &, 125 &, 332 & 2,123 &, 039 \\
& Pengembangan SDM &, 228 &, 106 &, 337 & 2,153 &, 036 \\
\hline
\end{tabular}

a. Dependent Variable: Komitmen Organisasi

Sumber : Hasil Olah Data, 2020

Dari hasil persamaan regresi pertama di atas, dijelaskan sebagai berikut:

$\mathrm{Y}_{1}=0,332 \mathrm{X}_{1}+0,337 \mathrm{X}_{2}+\epsilon$

Keterangan:

1. $\beta_{1}=$ koefisien regresi variabel motivasi sebesar 0,332 , hal ini menunjukan bahwa variabel Motivasi berpengaruh positif terhadap komitmen organisasi Pegawai di Dinas Sosial Kabupaten Magetan.

2. $\beta_{2}=$ koefisien regresi variabel Pengembangan SDM sebesar 0,337, hal ini menunjukan bahwa variabel pengembangan SDM berpengaruh positif terhadap komitmen organisasi Pegawai di Dinas Sosial Kabupaten Magetan.

Hasil Analisis Jalur Persamaan 2

Tabel 3. Hasil Analisis Jalur Persamaan 2

Coefficients $^{\mathrm{a}}$

\begin{tabular}{|ll|r|r|r|r|r|}
\hline \multirow{2}{*}{ Model } & \multicolumn{2}{|c|}{$\begin{array}{l}\text { Unstandardized } \\
\text { Coefficients }\end{array}$} & \multicolumn{2}{c|}{$\begin{array}{c}\text { Standardized } \\
\text { Coefficients }\end{array}$} & \multirow{2}{*}{} \\
\cline { 3 - 4 } & & \multicolumn{1}{|c|}{$\mathrm{B}$} & Std. Error & \multicolumn{1}{c|}{ Beta } & \multicolumn{1}{c|}{$\mathrm{t}$} & \multicolumn{1}{c|}{ Sig. } \\
\hline 1 & (Constant) & 4,762 & 2,342 & & 2,033 &, 048 \\
& Motivasi &, 218 &, 123 &, 235 & 1,768 &, 084 \\
& Pengembangan SDM &, 410 &, 104 &, 524 & 3,946 &, 000 \\
& Komitmen Organis asi &, 122 &, 137 &, 106 &, 895 &, 376 \\
\hline
\end{tabular}

a. Dependent Variable: Kepuasan

Sumber : Data yang diolah, 2020 
Dari hasil persamaan regresi kedua di atas, maka dijelaskan sebagai berikut: $\mathrm{Y}_{1}=0,235 \mathrm{X}_{1}+0,524 \mathrm{X}_{2}+0,106 \mathrm{X}_{3}+\epsilon$

Keterangan:

1. $\beta_{1}=$ koefisien regresi variabel Motivasi sebesar 0,235 , hal ini menunjukan bahwa variabel Motivasi berpengaruh positif terhadap kepuasan Pegawai di Dinas Sosial Kabupaten Magetan.

2. $\beta_{2}=$ koefisien regresi variabel Pengembangan SDM sebesar 0,524, hal ini menunjukan bahwa variabel Pengembangan SDM berpengaruh positif terhadap kepuasan Pegawai di Dinas Sosial Kabupaten Magetan.

3. $\mathrm{B}_{3}=$ koefisien regresi variabel komitmen organisasi sebesar 0,106 , hal ini menunjukan bahwa variabel komitmen organisasi berpengaruh positif terhadap kepuasan Pegawai di Dinas Sosial Kabupaten Magetan.

Hasil Analisis Jalur Persamaan 3

Tabel 4. Hasil Analisis Jalur Persamaan 3

Coefficients

\begin{tabular}{|c|c|c|c|c|c|c|}
\hline \multirow{2}{*}{\multicolumn{2}{|c|}{ Model }} & \multicolumn{2}{|c|}{$\begin{array}{l}\text { Unstandardiz ed } \\
\text { Coefficients }\end{array}$} & \multirow{2}{*}{$\begin{array}{c}\text { Standardized } \\
\text { Coefficients } \\
\text { Beta } \\
\end{array}$} & \multirow[b]{2}{*}{$\mathrm{t}$} & \multirow[b]{2}{*}{ Sig. } \\
\hline & & B & Std. Error & & & \\
\hline \multirow[t]{5}{*}{1} & (Constant) & 7,630 & 1,324 & & 5,764 &, 000 \\
\hline & Motivasi & ,208 & ,069 & ,274 & 3,013 & ,004 \\
\hline & Pengembangan SDM & ,137 & ,065 & ,215 & 2,110 & , 040 \\
\hline & Komitmen Organis asi & ,158 & 075 & ,168 & 2,119 & , 040 \\
\hline & Kepuasan & ,329 & ,080 & ,403 & 4,119 & ,000 \\
\hline
\end{tabular}

a. Dependent Variable: Kinerja Pegawai

Sumber : Data yang diolah, 2020

Dari hasil persamaan regresi kedua di atas, maka dijelaskan sebagai berikut:

$\mathrm{Y}_{3}=0,274 \mathrm{X}_{1}+0,215 \mathrm{X}_{2}+0,168 \mathrm{X}_{3}+0,403 \mathrm{X}_{4}+\epsilon$

Keterangan:

1. $\beta_{1}=$ koefisien regresi variabel Motivasi sebesar 0,274 , hal ini menunjukan bahwa variabel Motivasi berpengaruh positif terhadap kinerja Pegawai di Dinas Sosial Kabupaten Magetan.

2. $\beta_{2}=$ koefisien regresi variabel Pengembangan SDM sebesar 0,215, hal ini menunjukan bahwa variabel Pengembangan SDM berpengaruh positif terhadap kinerja Pegawai di Dinas Sosial Kabupaten Magetan.

3. $\beta_{3}=$ koefisien regresi variabel komitmen organisasi sebesar 0,168 , hal ini menunjukan bahwa variabel komitmen organisasi berpengaruh positif terhadap kinerja Pegawai di Dinas Sosial Kabupaten Magetan.

4. $\beta_{4}=$ koefisien regresi variabel kepuasan sebesar 0,403 , hal ini menunjukan bahwa variabel kepuasan berpengaruh positif terhadap kinerja Pegawai di Dinas Sosial Kabupaten Magetan. 


\section{Hasil Uji Hipotesis}

Hasil uji hipotesis dalam penelitian ini diantaranya adalah sebagai berikut:

1. Hasil Uji t Variabel Motivasi berpengaruh signifikan terhadap Komitmen organisasi. Hal ini dapat dilihat dari nilai signifikansi yaitu $0,039<0,05$. Sehingga hipotesis 1 terbukti.

2. Hasil Uji t Variabel Pengembangan SDM berpengaruh signifikan terhadap Komitmen organisasi. Hal ini dapat dilihat dari nilai signifikan yaitu 0,036 $<0,05$. Sehingga hipotesis 2 terbukti.

3. Hasil Uji t Variabel Motivasi berpengaruh tidak signifikan terhadap kepuasan Pegawai di Dinas Sosial Kabupaten Magetan, hal ini dapat dilihat dari nilai signifikan yaitu 0,084 >0,05. Sehingga hipotesis 3 tidak terbukti.

4. Hasil Uji t Variabel Pengembangan SDM berpengaruh signifikan terhadap kepuasan Pegawai di Dinas Sosial Kabupaten Magetan, hal ini dapat dilihat dari nilai signifikansi yaitu $0,000<0,05$. Sehingga hipotesis 4 terbukti.

5. Hasil Uji t Variabel komitmen organisasi berpengaruh tidak signifikan terhadap kepuasan Pegawai di Dinas Sosial Kabupaten Magetan, hal ini dapat dilihat dari nilai signifikansi yaitu $0,376>0,05$. Sehingga hipotesis 5 tidak terbukti.

6. Hasil Uji t Variabel Motivasi berpengaruh tidak signifikan terhadap kinerja Pegawai di Dinas Sosial Kabupaten Magetan, hal ini dapat dilihat dari nilai signifikansi yaitu $0,004<0,05$. Sehingga hipotesis 6 terbukti.

7. Hasil Uji t Variabel Pengembangan SDM berpengaruh signifikan terhadap kinerja Pegawai di Dinas Sosial Kabupaten Magetan, hal ini dapat dilihat dari nilai signifikansi yaitu $0,040<0,05$. Sehingga hipotesis 7 terbukti.

8. Hasil Uji t Variabel komitmen organisasi berpengaruh signifikan terhadap kinerja Pegawai di Dinas Sosial Kabupaten Magetan, hal ini dapat dilihat dari nilai signifikansi yaitu $0,040<0,05$. Sehingga hipotesis 8 terbukti.

9. Hasil Uji t Variabel kepuasan berpengaruh signifikan terhadap kinerja Pegawai di Dinas Sosial Kabupaten Magetan, hal ini dapat dilihat dari nilai signifikansi yaitu $0,000<0,05$. Sehingga hipotesis 9 terbukti.

\section{Uji F}

Tabel 4. Hasil Uji F

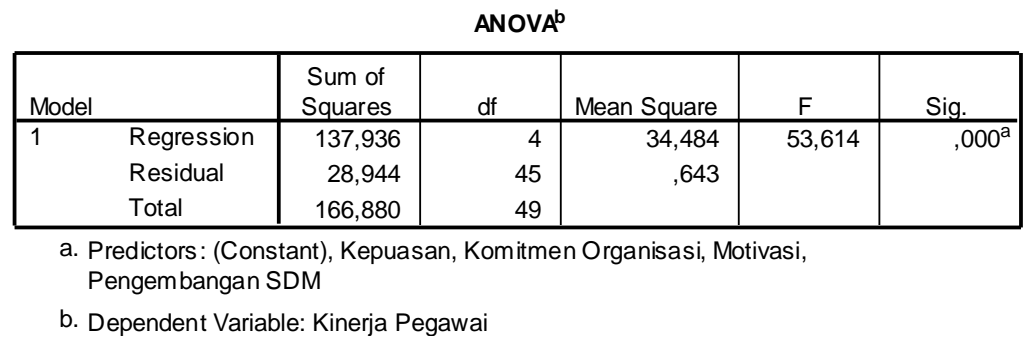

Sumber : Hasil Olah Data, 2020

Hasil uji secara serempak (Uji F) pada persamaan ketiga diketahui besarnya nilai $\mathrm{F}=53,614$ signifikansi $0,000<0,05$. Sehingga dapat disimpulkan secara bersama-sama variabel motivasi, pengembangan SDM, komitmen organisasi dan kepuasan mempengaruhi Kinerja pegawai di Dinas Sosial Kabupaten Magetan. 


\section{Hasil Uji Koefisien Determinasi}

Nilai $\mathrm{R}^{2}$ total sebesar 0,564 dapat diartikan variasi Kinerja Pegawai di Dinas Sosial Kabupaten Magetan dijelaskan oleh variabel Motivasi, Pengembangan SDM, Komitmen organisasi dan kepuasan sebesar 56,4\% dan sisanya 43,6\% dijelaskan variabel lain diluar model penelitian sebagai contoh kompetensi, pelatihan dan lain sebagainya.

\section{Hasil Perhitungan Pengaruh Langsung dan Tidak Langsung}

Tabel 5. Pengaruh Langsung, Pengaruh Tidak Langsung

\begin{tabular}{|c|c|c|c|}
\hline \multirow[t]{2}{*}{ Dari Variabel } & \multicolumn{2}{|c|}{ Koefisien Jalur } & \multirow[t]{2}{*}{ Total Pengaruh } \\
\hline & Langsung & Tidak Langsung & \\
\hline M $\rightarrow$ Keps & $P_{3}=0,235$ & & \\
\hline P SDM $\rightarrow$ Keps & $\mathrm{P}_{4}=0,524$ & & \\
\hline $\mathbf{M} \rightarrow \mathbf{K}$ & $\mathrm{P}_{6}=0,274$ & & \\
\hline $\mathbf{P} \mathbf{S D M} \rightarrow \mathrm{K}$ & $P_{7}=0,215$ & & \\
\hline M melalui Komt $\rightarrow$ Keps & & $\begin{array}{l}P_{1} \times P_{5}= \\
0,332 \times 0,106 \\
=0,035\end{array}$ & $\begin{array}{l}P_{3}+\left(P_{1} \times P_{5}\right)= \\
0,235+0,035 \\
=0,27\end{array}$ \\
\hline P SDM melalui Komt $\rightarrow$ Keps & & $\begin{array}{l}P_{2} \times P_{8}= \\
0,337 \times 0,106 \\
=0,036\end{array}$ & $\begin{array}{l}\mathrm{P}_{4}+\left(\mathrm{P}_{2} \times \mathrm{P}_{8}\right)= \\
0,524+0,036 \\
=0,56\end{array}$ \\
\hline M melalui Komt $\rightarrow$ K & & $\begin{array}{l}P_{1} \times P_{8}= \\
0,332 \times 0,168 \\
=0,056\end{array}$ & $\begin{array}{l}P_{6}+\left(P_{1} \times P_{8}\right)= \\
0,274+0,056 \\
=0,33\end{array}$ \\
\hline P SDM melalui Komt $\rightarrow$ K & & $\begin{array}{l}P_{2} \times P_{8}= \\
0,337 \times 0,168 \\
=0,057\end{array}$ & $\begin{array}{l}\mathrm{P}_{7}+\left(\mathrm{P}_{2} \times \mathrm{P}_{8}\right)= \\
0,215+0,057 \\
=0,272\end{array}$ \\
\hline M melalui Keps $\rightarrow \mathrm{K}$ & & $\begin{array}{l}\mathrm{P}_{3} \times \mathrm{P}_{9}= \\
0,235 \times 0,403 \\
=0,095\end{array}$ & $\begin{array}{l}\mathrm{P}_{6}+\left(\mathrm{P}_{3} \times \mathrm{P}_{9}\right)= \\
0,274+0,095 \\
=0,369\end{array}$ \\
\hline P SDM melalui Keps $\rightarrow$ K & & $\begin{array}{l}\mathrm{P}_{4} \times \mathrm{P}_{9}= \\
0,524 \times 0,403 \\
=0,211\end{array}$ & $\begin{array}{l}P_{7}+\left(P_{4} \times P_{9}\right)= \\
0,215+0,211 \\
=0,426\end{array}$ \\
\hline $\mathrm{M} \rightarrow \mathrm{Komt} \rightarrow \mathrm{Keps} \rightarrow \mathrm{K}$ & & $\begin{array}{l}0,332 \times 0,106 \times \\
0,168\end{array}$ & 0,006 \\
\hline $\mathrm{P} \rightarrow \mathrm{Komt} \rightarrow \mathrm{Keps} \rightarrow \mathrm{K}$ & & $\begin{array}{cccc}0,337 & \mathrm{x} & 0,106 & \mathrm{x} \\
0,403 & & & \end{array}$ & 0,014 \\
\hline
\end{tabular}

Sumber: Data diolah 2019 
Dari tabel di atas hubungan antar variabel dapat digambarkan dengan bagan sebagai berikut:

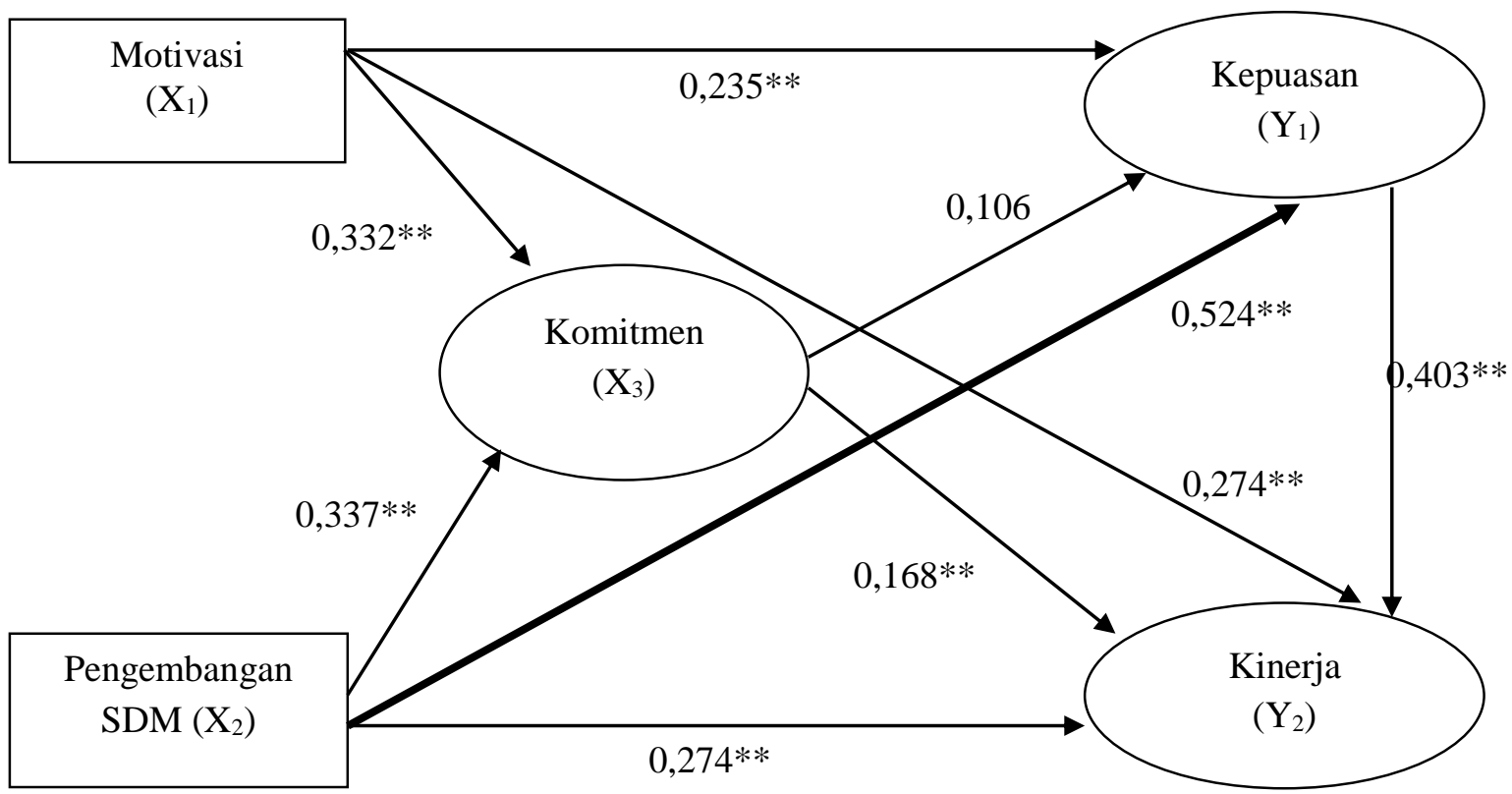

Gambar 1. Pengaruh Langsung Dan Tidak Langsung

\section{PEMBAHASAN}

\section{Pengaruh Motivasi Terhadap Kepuasan Melalui komitmen organisasi}

Dari hasil analisis pengaruh motivasi terhadap kepuasan melalui komitmen organisasi hasilnya lebih kecil dari pengaruh langsung. Pengaruh langsung lebih efektif digunakan untuk meningkatkan kepuasan. Maka sebaiknya variabel motivasi lebih ditingkatkan lagi agar kepuasan lebih optimal lagi. Hal ini sesuai hasil penelitian Keumala Hayati Indra Caniago (2012), Ferum Mahendra Pranita (2017), Edward Tio (2014) yang menyatakan bahwa motivasi berpengaruh signifikan terhadap kepuasan.

Maka langkah kongkrit yang perlu ditingkatkan agar kepuasan lebih meningkat adalah meningkatkan indikator tertinggi variabel motivasi adalah: Pengembangan pegawai melalui diklat atau studi lanjut dapat menjadi motivator peningkatan prestasi kerja pegawai, Pimpinan memberikan tanggung jawab kepada pegawai untuk bekerja mandiri, Prestasi yang dicapai oleh pegawai mendapat apresiasi dari pimpinan, Pimpinan memberikan pengakuan atas keberhasilan pegawai dalam melakukan pekerjaan dan Pegawai memperoleh kesempatan untuk bekerja dan berkarya untuk peningkatan prestasi.

\section{Pengaruh Pengembangan SDM Terhadap Kepuasan Melalui komitmen organisasi.}

Dari hasil analisis pengaruh Pengembangan SDM terhadap kepuasan Pegawai melalui komitmen organisasi menghasilkan nilai yang lebih kecil dari pengaruh langsung. Maka dapat diimplementasikan pengaruh tidak langsung pengembangan SDM terhadap kinerja melalui komitmen organisasi adalah tidak efektif. Maka sebaiknya pengembangan SDM lebih ditingkatkan agar kepuasan lebih optimal lagi. 
Hasil penelitian ini mendukung hasil penelitian yang dilakukan oleh Dhermawan (2012), Yunus (2009) menunjukkan bahwa pengembangan SDM berpengaruh signifikan terhadap kepuasan.

Maka langkah kongkrit yang perlu ditingkatkan merupakan indikator variabel pengembangan SDM, Selanjutnya langkah kongkrit yang direkomendsaikan adalah meningkatkan indikator tertinggi uji validitas pengembangan SDM antara lain: Pelatihan yang dilakukan Dinas Sosial Kabupaten Magetan demi pengembangan SDM yang berkualitas, Pengembangan SDM dilakukan untuk promosi suatu jabatan, Pengembangan SDM dilakukan untuk meningkatkan keterampilan dan pengetahuan pegawai, Penempatan pegawai Dinas Sosial Kabupaten Magetan sudah memperhatikan metode pengembangan jabatan pegawai dan Pengembangan SDM dilakukan untuk meningkatkan keahlian dan kecakapan memimpin serta mengambil keputusan atau managerial skills atau conceptual skills.

\section{Pengaruh Motivasi Terhadap Kinerja Melalui komitmen organisasi}

Dari hasil analisis pengaruh motivasi terhadap kinerja melalui komitmen organisasi hasilnya lebih kecil dari pengaruh langsung. Pengaruh langsung lebih efektif digunakan untuk meningkatkan kinerja. Maka sebaiknya variabel motivasi lebih ditingkatkan lagi agar kinerja lebih optimal lagi. Hal ini sesuai hasil penelitian Caniago (2012), Pranita (2017), Isa at al (2016), Adeyinka, (2017), Aninda (2011), Minaningsih (2014) yang menyatakan bahwa motivasi berpengaruh signifikan terhadap kinerja.

Maka langkah kongkrit yang perlu ditingkatkan agar kinerja lebih meningkat adalah meningkatkan indikator tertinggi variabel motivasi adalah: Pengembangan pegawai melalui diklat atau studi lanjut dapat menjadi motivator peningkatan prestasi kerja pegawai, Pimpinan memberikan tanggung jawab kepada pegawai untuk bekerja mandiri, Prestasi yang dicapai oleh pegawai mendapat apresiasi dari pimpinan, Pimpinan memberikan pengakuan atas keberhasilan pegawai dalam melakukan pekerjaan dan Pegawai memperoleh kesempatan untuk bekerja dan berkarya untuk peningkatan prestasi.

\section{Pengaruh Pengembangan SDM Terhadap Kinerja Melalui komitmen organisasi.}

Dari hasil analisis pengaruh Pengembangan SDM terhadap Kinerja Pegawai melalui komitmen organisasi menghasilkan nilai yang lebih kecil dari pengaruh langsung. Maka dapat diimplementasikan pengaruh tidak langsung pengembangan SDM terhadap kinerja melalui komitmen organisasi adalah tidak efektif. Maka sebaiknya pengembangan SDM lebih ditingkatkan agar kinerjanya lebih optimal lagi.

Hasil penelitian ini mendukung hasil penelitian yang dilakukan oleh Dhermawan (2012), menunjukkan bahwa pengembangan SDM berpengaruh signifikan terhadap kinerja pegawai.

Maka langkah kongkrit yang perlu ditingkatkan merupakan indikator variabel pengembangan SDM, Selanjutnya langkah kongkrit yang direkomendsaikan adalah meningkatkan indikator tertinggi uji validitas pengembangan SDM antara lain: Pelatihan yang dilakukan Dinas Sosial Kabupaten Magetan demi pengembangan SDM yang berkualitas, Pengembangan SDM dilakukan untuk promosi suatu jabatan, Pengembangan SDM dilakukan untuk meningkatkan keterampilan dan pengetahuan pegawai, Penempatan pegawai Dinas Sosial Kabupaten Magetan sudah 
memperhatikan metode pengembangan jabatan pegawai dan Pengembangan SDM dilakukan untuk meningkatkan keahlian dan kecakapan memimpin serta mengambil keputusan atau managerial skills atau conceptual skills.

\section{Pengaruh Motivasi Terhadap Kinerja Melalui kepuasan}

Dari hasil analisis pengaruh motivasi terhadap kinerja melalui kepuasan hasilnya lebih kecil dari pengaruh langsung. Pengaruh tidak langsung tidak efektif digunakan untuk meningkatkan kinerja. Maka sebaiknya variabel motivasi lebih ditingkatkan lagi agar kinerja lebih optimal lagi.

Hasil penelitian ini mendukung hasil penelitian yang dilakukan oleh Caniago (2012), Pranita (2017), Isa at al (2016), Adeyinka, (2017), Aninda (2011), Minaningsih (2014) yang menyatakan bahwa motivasi berpengaruh signifikan terhadap kinerja.

Maka langkah kongkrit yang perlu ditingkatkan agar kinerja lebih meningkat adalah meningkatkan indikator tertinggi uji validitas variabel motivasi adalah: Pengembangan pegawai melalui diklat atau studi lanjut dapat menjadi motivator peningkatan prestasi kerja pegawai. Pimpinan memberikan tanggung jawab kepada pegawai untuk bekerja mandiri, Prestasi yang dicapai oleh pegawai mendapat apresiasi dari pimpinan, Pimpinan memberikan pengakuan atas keberhasilan pegawai dalam melakukan pekerjaan dan Pegawai memperoleh kesempatan untuk bekerja dan berkarya untuk peningkatan prestasi.

\section{Pengaruh Pengembangan SDM Terhadap Kinerja Melalui kepuasan}

Dari hasil analisis pengaruh pengembangan SDM terhadap kinerja melalui kepuasan hasilnya lebih kecil dari pengaruh langsung. Pengaruh tidak langsung tidak efektif digunakan untuk meningkatkan kinerja. Maka sebaiknya variabel pengembangan SDM lebih ditingkatkan lagi agar kinerja lebih optimal lagi.

Hasil penelitian ini mendukung hasil penelitian yang dilakukan oleh Dhermawan (2012) yang menyatakan bahwa pengembangan SDM berpengaruh signifikan terhadap kinerja.

Maka langkah kongkrit yang perlu ditingkatkan agar kinerja lebih optimal adalah meningkatkan indikator tertinggi uji validitas variabel pengembangan SDM, diantaranya adalah sebagai berikut: Pelatihan yang dilakukan Dinas Sosial Kabupaten Magetan demi pengembangan SDM yang berkualitas, Pengembangan SDM dilakukan untuk promosi suatu jabatan, Pengembangan SDM dilakukan untuk meningkatkan keterampilan dan pengetahuan pegawai, Penempatan pegawai Dinas Sosial Kabupaten Magetan sudah memperhatikan metode pengembangan jabatan pegawai, Pengembangan SDM dilakukan untuk meningkatkan keahlian dan kecakapan memimpin serta mengambil keputusan atau managerial skills atau conceptual skills.

\section{KESIMPULAN}

1. Hasil Uji Hipotesis adalah:

a. Motivasi berpengaruh signifikan terhadap komitmen organisasi pada Dinas Sosial Kabupaten Magetan.

b. Pengembangan SDM berpengaruh signifikan terhadap komitmen organisasi pada Dinas Sosial Kabupaten Magetan 
c. Motivasi berpengaruh tidak signifikan terhadap kepuasan pada Dinas Sosial Kabupaten Magetan

d. Pengembangan SDM berpengaruh signifikan terhadap kepuasan pada Dinas Sosial Kabupaten Magetan.

e. Komitmen organisasi berpengaruh tidak signifikan terhadap kepuasan pada Dinas Sosial Kabupaten Magetan.

f. Motivasi berpengaruh signifikan terhadap kinerja pegawai pada Dinas Sosial Kabupaten Magetan.

g. Pengembangan SDM berpengaruh signifikan terhadap kinerja pegawai pada Dinas Sosial Kabupaten Magetan.

h. Komitmen organisasi berpengaruh signifikan terhadap kinerja pegawai pada Dinas Sosial Kabupaten Magetan.

i. Kepuasan berpengaruh signifikan terhadap kinerja pegawai pada Dinas Sosial Kabupaten Magetan.

2. Hasil Analisis Jalur:

a. Pengaruh motivasi terhadap kepuasan melalui komitmen organisasi lebih kecil dari pengaruh langsung sehingga jalur ini tidak efektif.

b. Pengaruh pengembangan SDM terhadap kepuasam kerja melalui komitmen organisasi lebih kecil dari pengaruh langsung sehingga jalur ini tidak efektif.

c. Pengaruh motivasi terhadap kinerja melalui komitmen organisasi lebih kecil dari pengaruh langsung sehingga jalur ini tidak efektif.

d. Pengaruh Pengembangan SDM terhadap kinerja melalui komitmen organisasi lebih kecil dari pengaruh langsung sehingga jalur ini tidak efektif.

e. Pengaruh motivasi terhadap kinerja melalui kepuasan lebih kecil dari pengaruh langsung sehingga jalur ini tidak efektif.

f. Pengaruh Pengembangan SDM terhadap kinerja melalui kepuasan lebih kecil dari pengaruh langsung sehingga jalur ini tidak efektif.

g. Pengaruh pengembangan SDM terhadap kepuasan merupakan variabel paling efektif karena memiliki nilai paling dominan.

\section{SARAN}

1. Pengembangan SDM hal yang perlu diperhatikan untuk ditingkatkan. Hal yang dapat dilakukan dalam meningkatkan pengembangan SDM antara lain : Pelatihan yang dilakukan Dinas Sosial Kabupaten Magetan demi pengembangan SDM yang berkualitas, Pengembangan SDM dilakukan untuk promosi suatu jabatan, Pengembangan SDM dilakukan untuk meningkatkan keterampilan dan pengetahuan pegawai, Penempatan pegawai Dinas Sosial Kabupaten Magetan sudah memperhatikan metode pengembangan jabatan pegawai, Pengembangan SDM dilakukan untuk meningkatkan keahlian dan kecakapan memimpin serta mengambil keputusan atau managerial skills atau conceptual skills.

2. Motivasi perlu ditingkatkan, agar kinerja pegawai dapat meningkat, maka langkah kongkrit yang perlu ditingkatkan agar kinerja lebih meningkat adalah meningkatkan indikator tertinggi uji validitas variabel motivasi adalah: Pengembangan pegawai melalui diklat atau studi lanjut dapat menjadi motivator peningkatan prestasi kerja pegawai, Pimpinan memberikan tanggung jawab kepada pegawai untuk bekerja mandiri, Prestasi yang dicapai oleh pegawai mendapat apresiasi dari pimpinan, Pimpinan memberikan pengakuan atas keberhasilan pegawai dalam 
melakukan pekerjaan, Pegawai memperoleh kesempatan untuk bekerja dan berkarya untuk peningkatan prestasi

3. Bagi peneliti yang akan datang hendaknya dapat memperhatikan variabel intervening karena pada penelitian ini belum bisa memediasi dan menjadikan pengaruh tidak efektif.

\section{DAFTAR PUSTAKA}

Adeyinka Tella, C.O Ayeni, S,O. Popoola, Ph D. 2012. Work Motivation, Job Satisfaction And Organizational Commitment of Library Personnel in Academic and Research Libraries in Oyo State, Nigeria. Journal Library Philoshophy and Practice

Ambar, Teguh Sulistiyani, 2013. Memahami Good Governance: Dalam Perspektif Sumber Daya Manusia, Penerbit Gava Media, Yogyakarta.

Arikunto, Suharsimi. 2013. Prosedur Penelitian: Suatu Pendekatan Praktek. Jakarta: Rineka Cipta.

Armstrong Michael, 2012. Manajemen Sumber Daya Manusia. Jakarta : PT. Elex Media Komputindo.

As'ad, Mohamad. 2013. Psikologi Industri. Yogyakarta: Liberty.

Davis, Keith, \& Jhon W. Newstrom, 2016. Manajemen Sumber Daya Manusia. Yogyakarta: BPFE

Dhermawan dkk. 2012. Pengaruh Motivasi, Lingkungan kerja, kompetensi, dan Kompensasi Terhadap Kepuasan Kerja dan Kinerja Pegawai di Lingkungan Kantor Dinas Pekerjaan Umum Provinsi Bali Jurnal Manajemen, Strategi Bisnis, dan Kewirausahaan. Vol.6 No.2 Hal. 173-184.

Eddy Yunus . 2013. Pengaruh Kompetensi Sumber Daya Manusia Terhadap Kinerja Pegawai Kppbc Madya Pabean Tanjung Perak Surabaya Jurnal Ekonomi dan Keuangan ISSN 1411 - 0393 Akreditasi No-110/Dikti/Kep/2009

Edward Tio . 2014. The Impact Of Working Environment Towards Employee Job Satisfaction: A Case Study In Pt. X iBuss Management Vol. 2, No. 1, (2014) 15.

Endang Wismawati .2013, Masalah Komitmen Organisasional Dan Kinerja, Journal.Resources Review vol 1 no 12

Ferum Mahendra Pranita. 2017. Influence of Motivation and Organizational Commitment on Work Satisfaction and Employee Performance Proceeding of ICECRS, 1 (2017) 24-31. ISSN. 2548-6160 ICIGR 2017, 24-25 November 2017, Universitas Muhammadiyah Sidoarjo, Indonesia

Fuad, Mas'ud. 2013. Survai Diagnosis Organisasional: Konsep \& Aplikasi. Semarang: Badan Penerbit Universitas Diponegoro.

Gibson, James L., John M. Ivancevich, James H. Donnelly, Jr.Robert Konopaske 2013. Organizations: Behavior, Structure, Processes. Thirteenth Edition. International Edition .New York : McGraw-Hill/Irwin.

Gujarati., Damodar., 2013, Ekonometrika Dasar, Penerbit Erlangga, Jakarta.

Handoko, Hani., 2012, Manajemen, Edisi 2 Cetakan Kedelapanbelas, BPFE, Yogyakarta.

Hessel, Nogi Tangkalisan, 2012. Manajemen Publik, Grasindo, Jakarta.

Hasibuan Malayu, 2012. Manajemen Sumber Daya Manusia. Jakarta: Bumi Aksara. 
Keumala Hayati Indra Caniago, 2012. Islamic Work Ethic : The Role of Intrinsic Motivation, Job Satisfaction, Organizational Commitment and Job Performance . Procedia - Social and Behavioral Sciences 65 ( 2012 ) 272 - 277

Luthans, Fred. 2014. Organizational Behavior. Eleventh Edition. New York: McGrawHill / Irwin.

Mahsun, Muhammad, 2012. Pengukuran Kinerja Sektor Publik, BPFE, Yogyakarta.

Mangkunegara, Anwar Prabu, 2014. Manajemen Sumber Daya Manusia Perusahaan, Cetakan Ketujuh, PT. Remaja Rosdakarya, Bandung.

Manulang, 2014. Manajemen Personalia. Yogyakarta: Gadjah Mada University Press.

Nurul Hasanah Mat Isa , at al. 2016 Relationship Between Motivation and Commitment on Job Performance among Employees in Higher Education from Students' Perspective World Applied Sciences Journal 34 (3): 400-407, 2016. ISSN 18184952 @ IDOSI Publications, 2016

Pabundu, Tika. 2014. Budaya Organisasi dan Peningkatan Kinerja Perusahaan. Jakarta : Bumi Aksara.

Riduwan, (2013), Skala Pengukuran Variabel-variabel Penelitian, cetakan ketiga, Alfabeta, Bandung.

Sarwono, Jonathan. 2012, Analisis Jalur Untuk Bisnis dengan SPSS, Andi Offset Jogyakarta.

Siagian, Sondang P., 2012, Manajemen Sumber Daya Manusia Edisi I, PT. Bumi Aksara, Jakarta.

Sugiyono. 2013. Metodologi Penelitian Bisnis. Bandung: Alfabeta.

Sekaran, Uma, 2013, Research Methods For Business : A Skill Building Approach, John Wiley \& Sons, Inc, New York.

Sovyia Desianty, 2016, Pengaruh Gaya Kepemimpinan Terhadap Komitmen Organisasi Pada PT Pos Indonesia (PERSERO) Semarang". Jurnal Studi Manajemen \& Organisasi. Vol 2. No. 1

Steers, Richard M and Lyman W, Porter, 2017, Motivation and Work Behavior, Mc Graw Hill Book Co, New York.

Thoha, Miftah., 2016, Perilaku Organisasi, Rajawali Press, Yogyakarta.

Trisnaningsih S, 2012, Pengaruh Komitmen Terhadap Kepuasan Kerja Auditor Motivasi sebagai Variabel Intervening (Studi Empiris Pada Kantor Akuntan Publik di Jawa Timur), Jurnal Riset Akuntansi Indonesia, Vol 6, No. 2, Mei 2008 Hal 199-216.

Veithzal, Rivai \& Ahmad Fawzi Mohd. Basri, 2017, Manajemen Sumber Daya Manusia, Jakarta, Ghalia Indonesia.

Wursanto. 2018. Dasar-Dasar Ilmu Organisasi. Penerbit Andi. Yogyakarta 